\title{
The Legal Analysis of the Right to Reparation for the Victims of the Human Rights Violations in the European, Inter-American and African Human Rights Protection Systems
}

\author{
Aslan Khuseinovich Abashidze, Christina Otarovna Keburia* and \\ Alexander Mikhailovich Solntsev \\ Department of International Law, RUDN University, Moscow, Russian Federation; Abashidze_akh@pfur.ru, \\ ch.keburia@gmail.com,solntsev_am@pfur.ru
}

\begin{abstract}
Background/Objectives: The right to reparation is the core element of the human rights protection. The article is aimed to analyze the theory of the rights to reparation and practice of the three existing regional systems of human rights protection in this field. Methods: The article used scientific methodological approach to determine the entire and main aspects and concepts of the research. It also applied the comparative method to analyze core similarities and significant differences between the three regional systems on the right to reparation, the scientific methods of cognition, the method of generalization, system-structural method and also such special methods of science as: legal and technical, historical and forecasting methods. Findings: In the conclusion the authors come to the point that all three systems for the protection of human rights have significant developments in regard to the reparation. Despite of the historical fact that the InterAmerican and African mechanisms for human rights protection having established after the European system, obviously, took their lead from the European practice, they developed own approach to the reparation issues that appears even in the procedural matters. Taking into account some different interpretations of the right to reparation and its very specific character, proved by the role of this right in the whole concept of the protection of human rights, the practice of international instruments should be researched in order to understand not only theoretical development but opportunities of practical realization. Application/Improvements: It is useful to study their experience of all human rights protection systems and to accumulate mutual practices and the application of certain measures in the local context.
\end{abstract}

Keywords: African Rights Protection System, European Rights Protection System, Human Rights Protection, Human Rights Violations, Inter-American human Rights Protection System, Right to Reparation

\section{Introduction}

One of the major positions of the International human rights law, beyond promotion and protection of the human rights in broad meaning, comes to specific obligations on States in order to implement of fundamental rights and freedoms of every human being. The right to reparation as the response in cases of the human rights violations is confirmed in many international treaties protecting the human rights, and additionally performed in the practice of international universal and regional judicial and quasi-judicial bodies. One cannot insist on that the very system of the protection of human rights could function effectively without the recognized right of a person or a group of persons to claim for reparation when the harm is done, would not be effective and even would be meaningless. In cases where the victims may not receive reparation from the State for damage suffered, they have the ability to address the relevant regional and universal international mechanisms considering the human rights complaints.

Court regulations are binding for all stakeholders involved in the consideration of a particular dispute, whereas decisions of quasi-judicial bodies are only

*Author for correspondence 
advisory by their nature. Various State duties are complementary and not mutually exclusive.

The year of 2005 in this sphere is remarkable for the adoption of the UN Basic Principles and Guidelines on the Right to a Remedy and Reparation for Victims of Gross Violations of International Human Rights Law and Serious Violations of International Humanitarian Law (hereinafter - the UN Basic Principles and Guidelines) ${ }^{1}$ after continuous work in codification of the relevant norms in the sphere of reparation motivated a lot of scholars to research this topic which is hard to overestimate. Author ${ }^{2-10}$ should be mentioned in this regard. One of the fundamental works concerning reparation and remedy of which reparation is a part is Remedies in International Human Rights Law by ${ }^{11}$.

\section{Concept Headings}

The main goal of this article set by the authors is to provide legal analysis of the normative grounds and practical instruments for enforcement of the right to reparation for victims of human rights violations in three present regional human rights systems- the European, the InterAmerican and the African. The article used scientific methodological approach which facilitates to determine the whole canvas of the research, identify the main aspects and concepts of the study. The authors also widely applied the comparative method in order to analyze core similarities and to clarify significant differences between the European, Inter-American and African systems for human rights protection. The research used scientific methods of cognition, i.e., analysis, dialectics and synthesis, the method of generalization and systemstructural method. The article also practiced special methods of science such as: Legal and technical, historical and forecasting methods.

\section{Results and Discussion}

The adoption of the UN Basic Principles and Guidelines which are the first comprehensive codification of the right to reparation for victims of violations of international human rights to a remedy, reparation and access to justice, was issued on April 13, 2005 at the 61th session of the late UN Human Rights Commission, in Geneva ${ }^{12}$, with 40 votes "for" and 13 votes abstained (see Notes ${ }^{\star}$ ). Being the major guidance in the conception of reparation, the UN Basic Principles and Guidelines "do not entail new international or domestic legal obligations but identify mechanisms, modalities, procedures and methods for the implementation of existing legal obligations under international human rights law and international humanitarian law which are complementary though different as to their norms" (Preamble) ${ }^{1}$. Principle 11 of the UN Basic Principles and Guidelines declares that "remedies for gross violations of international human rights law and serious violations of international humanitarian law include the victim's right to the following as provided for under international law:

- Equal and effective access to justice.

- Adequate, effective and prompt reparation for harm suffered.

- Access to relevant information concerning violations and reparation mechanisms" ${ }^{1}$.

According to the above said, the opportunity to recover violated human rights in the process within effective, impartial and independent judicial or administrative body, with recognizing the harm suffered by victim or victims, the cessation of continuing violation are included in the essence of the right to a remedy. The ability to receive legal protection along with effective investigation of the breaches of the provisions of the human rights instruments can be the basic grounds for reparation to the victim/victims suffered. Due to the above mentioned, the UN Basic Principles and Guidelines see reparation as an inherent part of the remedy.

As it comes from the practice of the European Court and the notion of "victim" in Article 25 of the European Convention for the Protection of Human Rights and Fundamental Freedoms of 1950 (hereinafter - the European Convention) $)^{13}$, the Convention mentions the person directly suffered by an act or omission of the State harmed his/her rights confirmed in the Convention anyhow, if reparation has or has not been. Consequently, a decision or action issued by the European Court in favor of the applicant, in principle, is not sufficient to deprive him of his "victim" status unless the national authorities have acknowledged that and have not provided reparation for the violation of a particular article of the European Convention.

Considering that the European Court may not name a person a victim, it still can give this person status of a 
victim due to the meaning of Article 41 of the European Convention. For example, in Aksoycase the Court ruled compensation to the father of the direct victim, considering not only the sufferings caused to his child, but his own, even if was not established a direct violation of the father's rights ${ }^{14}$.

Possible distinction between the notion of "victim" and "person entitled to reparation" becomes clear in the cases of Çakici and of Aktas, where the relatives of the applicants had disappeared, but the European Court decided that there was not any violation of the European Convention's provisions against the rights of the applicants, "it undoubtedly influenced by the violation, the Court respectively may treat it as a victim within the meaning of Article 41"15,16.

As in the framework of the African human rights system and of the Inter-American human rights system the victim is considered to be a person whose rights have been violated by the unlawful actions or omissions of those who represent the State. The close connection of the right to reparation of those who suffered not being the direct victims, i.e., indirect victims, according to the relationship with the direct victim, has also been confirmed by the practice of the African Commission on Human and Peoples Rights (hereinafter- the African Commission), which recommended to compensate the suffering of the widows of the victims of extrajudicial executions ${ }^{17}$.

The Inter-American Court of Human Rights (hereinafter- the Inter-American Court) has ruled, in its turn, if we can state close relationship between the relatives, namely, mothers, fathers, children, siblings, spouses and the permanent companions ${ }^{18}$, thus, it goes beyond the common understanding of the indirect victims, only those who are closely connected to the victim (i.e., next of kin). The Inter-American Court confirmed that other family members should prove the special link with the direct victim. These special relationships may also exist between the direct victim and his or her grandparents and cousins: "Adequately identified immediate next of kin are the direct descendants or ancestors of the alleged victim, namely: Mother, father, children, brothers and sisters, spouse or permanent companion, or those defined by the Court on the basis of the circumstances of the case and the existence of any special relationship between close relatives and victims of human rights violations"19.

As for the collective reparation the human rights mechanisms have developed different criteria for determining the groups who have the right to collective reparation. The European Convention in its Article 34 states that "the Court may receive applications from any person, nongovernmental organization or group of individuals claiming to be the victim of a violation". The African Commission, for example, stated that the acceptance of the different individuals as peoples must be supported by "a link between these people, their land and culture... and in addition, individual identity as one people"20. The Inter-American Court shares similar position, which connects the indigenous peoples to their ancestral lands, defining cultural features, life style, religious particularities and existence.

Principles and Guidelines on the Right to a Fair Trial and Legal Assistance in Africa contain some provisions on the right to reparation, focused on the victims to which it is required to display a maximum of sympathy and respect for his or her dignity, and ensure prompt access to the measures of reparation (Section $\mathrm{N}(\mathrm{a})$ ) $^{21}$. It is important to understand the position of the specific victim, including aspects such as gender, culture and circumstances of life, and the relationship of these factors to the violation- for the adequacy and effectiveness of the reparation.

Article 46 of the 1981 African Charter on Human and Peoples' Rights ${ }^{22}$ (hereinafter- the African Charter) also confirms the authority of the African Commission to provide "field investigations". Moreover, Article 58 contains the provision according to which the African Commission, at the request of the Assembly of Heads of State and Government, to perform "in-depth study" when there are serious or massive human rights violations, followed by the preparation of a comprehensive report ${ }^{23}$.

The Inter-American Court insisted that the commitment to ensure adequate and effective reparation needed a straight connection between the violation, contested damage, as well as measures to repair the violated rights $^{24,25}$. In exceptional cases, the Court, taking into account the above-mentioned, may decide to designate a particular type of reparation for damage, even if it did not declare any of the parties, but in order to ensure adequate reparation ${ }^{26}$. It is significant that the suffered persons should have equal conditions to obtain any type of reparation. So, the discriminatory approach is forbidden, both in the universal and regional instruments and systems.

According to Article 41 of the European Convention, 
the first duty to carry out reparation for violations of human rights enshrined in the Convention, is to be imposed on the States ${ }^{27}$. To say this means that Article 41 corresponds to the essential principle of international law confirming that the States are obliged to create measures for effective and prompt performance of reparation for the harmed persons suffered from the States' violation of norms of international $\mathrm{law}^{28}$. This means that the winning applicant in the process within the European Court which confirmed the human rights violations, shall not, for the second time, exhaust domestic remedies before they can apply for reparation ${ }^{29}$.

The essential difference between the European, the African and the Inter-American systems begins with absence of a special article in the African Charter on the right of reparation, and just Article 21 thereof covers the cases of plundering the natural resources stating "the disposed people shall have the right to the lawful recovery of its property as well as to adequate compensation"22. The European Convention (Articles 5(5), 13 and 41) and the 1969 American Convention on Human Rights (hereinafter- the American Convention) ${ }^{30}$ (Articles 25, 63(1) and 68) in contrast both have clearly defined the opportunity of person/persons who had to become victims of the human rights violations to access to the rights of remedy and of reparation.

The European Court in some way being equal to the African Commission in the following confined approach to the reparation and leaving the definition of the reparation measures mostly to the free will of the State. Nevertheless, there is an implementation mechanism in the European system the analogue of which is not constructed for the African and the Inter-American systems- the Committee of Ministers of the Council of Europe, which has the mandate to control over the enforcement of the European Court's rulings within the States. In addition, the Committee of Ministers can help in the enforcement procedure of judgments, for example, by comprehensive guidance on the practical steps that States should use for the execution of the Court's decisions.

It should be noted that there is some procedural difference between the European, African and InterAmerican systems when it comes to the requirements for compensation of the alleged victims for harm they suffered. The European system nowadays has only the European Court for considering the cases of the human rights violations. The African Commission, if necessary, may transfer the case to the African Court on Human and Peoples Rights (hereinafter- the African Court), for example, in case of serious or massive violations of human rights or if the Commission finds the respondent State failed to execute its recommendations ${ }^{31}$. The InterAmerican human rights system has the similar procedure, where the Inter-American Commission on Human Rights (hereinafter - the Inter-American Commission) has the mandate to transfer cases to the Inter-American Court $^{32}$. However, there is an essential difference towards the procedural rights of the applicant in the transfer of the case, thus, paragraph 3 of Article 44 of the Rules of procedure of the Inter-American Commission has a provision, according to which the Commission must inform the applicant about the opportunity to claim to the respondent State for damages or any other expenses before the case will be referred to the Inter-American Court. After an appeal brought before the Inter-American Court, Article 24 of Rules of Procedure contains the provision in accordance with which the alleged victims or their legal representatives may present their statements and evidence during the trial.

According to Article 41 of the European Convention, reparation may be granted when there is:

- Material loss.

- Non-pecuniary damage.

- The costs and expenses.

As a result, a precise causal relation should be between the possible violation and the harm. The European Court, likewise the African Commission and African Court and the Inter-American Commission and Inter-American Court do not decide on reparation when any ambiguity or indirect evidence of violation of human rights was the cause of occurring adverse consequences for the suffered person. The purpose in the definition of reparation is the suffering of the victim, firstly, and then the recovery of the violated rights and creation of the conditions to prevent the wrong doing State from possible recurrence of such situation.

The UN Basic Principles and Guidelines contain the following types of reparation: Restitution, compensation, satisfaction, rehabilitation and guarantees of nonrepetition. It is interesting to note that the 2001 Draft Articles on Responsibility of States for Internationally Wrongful Acts (hereinafter- the Draft Articles) providing in Article 34 "full reparation" to use it "either singly or in 
combination" in the forms of restitution, compensation and satisfaction. ${ }^{33}$ Consequently, the Draft Articles, as compared to the UN Basic Principles and Guidelines, include only three types of reparation.

Restitution: Permanent Court of International Justice emphasized that the main aim of reparation is restitution $^{34}$, which was reaffirmed by the European Court in the Papamichalopouloscase, when the Court ruled that "a decision in which the Court finds a breach imposes a legal obligation to put an end to the respondent State infringement and compensate for its consequences in such a way as to restore as far as possible the situation existing before the breach" ${ }^{35}$.

For example, in the Elci and others case the victims of arbitrary detention and ill-treatment could not prove that they had lost earnings during their stay in prison. However, the European Court decided that the applicants truly have been illegally imprisoned and subjected to illtreatment by the competent authorities and confirmed that, despite the impossibility to present any other abovementioned evidences, the unlawful detention if enough to award the reparations for the victims for loss of earnings, which was eventually going to counterbalance to the position of Article 5 of the European Convention ${ }^{36}$.

Restitutio in integrum or restitution, as noted above, is considered the form of reparation to which victims should address firstly. It comes to the certain goal of changing the position to what occurred before the violation. If the restitution can be applied, it ceases the violation and, what is more important, "corresponds to the needs and wishes of the victim" ${ }^{37}$. However it is not always possible to use restitution, then Article 46 (1) of the European Convention establishes different ways of reparation ${ }^{38}$. States have broad choice of using an alternative type to repair damages, which can be individual measures to assist the victim and/r to win the problem as a whole ${ }^{39}$.

The European Court uses the reparation as an output of a legally binding nature of its decisions and restitution is the main type of reparation: "The Court notes that in accordance with Article 53 of the Convention the High Contracting Parties are bonded to follow the decisions of the Court in any case to which they are parties". In accordance with Article 54 it is provided that the Court's rulings are to be referred to the Committee of Ministers, which is to monitor their enforcement. So the ruling, in which the Court confirms the violation, creates a duty for the State-violator to stop the violation and compensate for the consequences happened for the victim, such as to restore the situation if it is possible to the status it had before the event of violation ${ }^{39}$.

The African Commission also recognized the significance of restitution, and ruled that the State when violation of the rights is confirmed in the African Charter has to "take all measures to ensure that victims of human rights violations, effective remedies, including restitution and compensation" ${ }^{\prime \prime}$.

The UN Basic Principles and Guidelines include, inter alia, the provision according to which restitution also consists in the restoration of nationality and movement back to one's place of living. For example, in the John K. Modisecase, the applicant, resident of the South Africa and coming from the family of father-citizen of Botswana and mother-citizen of the South Africa and transported by his father after his mother died in Botswana, was denied citizenship of this State. The African Commission confirmed the violation of certain Articles of the African Charter and proposed to Botswana not to prevent Mr. Modise to obtain citizenship to which he is entitled due to his origin ${ }^{41}$.

In the John D. Oukocase the applicant proved, inter alia, his forced movement from Kenya caused by his political beliefs and the African Commission finding the violation of Article 12 of African Charter by Kenyan government recommended to return the applicant safely to his homeland, if he still wishes to return ${ }^{42}$.

Recovery of illegally seized property right is another type of restitution presented in the experience of the African Commission. For example, the Endoroiscase examined by the African Commission ended up with recognition the unlawful movement of indigenous people from their traditional land of living, and recommendation to the State to recognize the land rights of these people, and to give them the opportunity to move back to their historical land ${ }^{43}$.

The same approach is performed with regard to arbitrary detention. In this sphere, the Inter-American Court stated that in case of conviction in an unfair trial, the victim is entitled to demand a judicial review of the case, to annul a conviction and to reimburse damages ${ }^{44}$.

Of course, not all types of reparation are applied in each case of human rights violations. Consequently, if restitution is possible, other forms are not used. Nevertheless, when restitutio in integrum could not be applied, other forms of reparation should be used in order to remedy the harm.

Compensation is in short a monetary estimate of the 
human rights violations, nonessential if the damage is material or moral ${ }^{45}$. The goal of monetary reparation or compensation, is to "provide reparation only in cases in which restitution is not applicable" ${ }^{36}$. If the restitution cannot be achieved at the national level, the European Court can, due to Article 41, decide to award the harmed person/persons the fair compensation for both material and moral suffering.

It seems clear that the decision on the compensation is issued only if the Court finds the violation of the European Convention, and the applicant successfully proves a straight connection between the violation incurred and its consequences and the action or omission of the State ${ }^{47-49}$.

The compensation is determined in accordance with the principle of fairness, which in fact, however, does not clarify the mechanism for calculation of the exact sum of money ${ }^{50}$. Due to the complexity to prove that the property damage was a result of the human rights violations, the European Court, to a greater extent, determines sums of compensation for moral harm ${ }^{37}$.

The European Court makes a decision on the State's duty to provide compensation to the victims harmed by moral damages or exposed to any mental or physical harm. If the location of the victim is unknown or the person is dead, the Court awards compensation for moral damages to the heirs and relatives of the direct victim51. The victim is not obliged to prove that he/she had suffered by mental harm, nevertheless its presence can be confirmed as a result of gross violation. Thus, the Orhan and Selcuk and Asker cases were ended by the European Court by the decision that the State must compensate for "moral damage", based on the severity of the violation, or in cases of serious human rights abuses or torture the Court operates with the simple fact of proven violations ${ }^{52}$.

Determining the exact amount of compensation is a necessary, albeit difficultly attainable factor in the field human rights. The Inter-American Court has developed an extensive practice of awarding specific amounts of monetary compensation when it is material and moral harm. It has, for example, developed the practice of decision-making in cases of unlawful alienation of property, forced evictions, and others. The Inter-American Court counts compensation for moral damages according to "reasonableness and fairness" 53 .

When counting of the lost property it is too complex to determine an accurate estimate of the material damage, the Inter-American Court stated that the arbitral tribunal shall determine the sum of the lost, as it happened in the Chaparro Alvarez case, where the victim was affected by the government actions to seizure his plant. Then, the Court proceeded to count the approximate amount of compensation according to the grounds of justice ${ }^{54}$.

The African Commission and the African Court had not worked out the factors for calculating the compensation in their practice. The only precedent in which the African Commission has departed from the practice of not determining the specific sum of compensation is the Egyptian Initiative for the Individual Rights of the International Centre for the Legal Protection against Egyptcase where, in finding the violation of the human rights of the applicants by Egypt, the African Commission counted the sum of compensation, however, not explaining the calculation methods ${ }^{55}$.

Rehabilitation: The right to reparation and the rehabilitation being one of its forms is a complex concept, and usually refers to the State's duty, which violated by its actions or omission the rules of international law on human rights, and as a significant element of the compensation measures. But to ensure the rehabilitation depends on many different factors, related both to government bonds and to the victims themselves.

The government's willingness to create measures for rehabilitation procedures to victims cannot be overstated, as without effective reparation in the scope of rehabilitation. However, one should take into account special issues related to victims, such as the level of the person's trust to the State on obtaining the necessary rehabilitation procedures. In addition, there is the problem of what is meant by rehabilitation procedures. As a rule, they include mainly medical services or a large range of other commonly used forms of assistance, such as training and education, housing, legal assistance, etc.

All of the three regional human rights protection systems know very well the rehabilitation as the type of the reparation. The African Commission recommends to the States recognized as the human rights abusers to pay compensation for "physical and psychological trauma", without which it is difficult to provide a complete rehabilitation. Thus, in the Purohit and Moore case, the African Commission, recognizing the State as the violator of Article 5 of the African Charter in relation to detention in a psychiatric institution of mentally ill persons, recommended to bring in the proper state of domestic legislation in the field of mental condition, in compliance 
with the African Charter and the practice of assistance to persons suffered from psychological disorders ${ }^{56}$.

The Inter-American Court differently evaluates medical assistance, both through compensation and, even in rehabilitation measures. To illustrate this statement we have to mention here the Aloeboetoe case where the Inter-American Court decided that the State must create a medical facility in the village where the persons lived who were harmed after the gross violations of their rights ${ }^{57}$.

Satisfaction: The European, African and Inter-American human rights protection systems require the States to take measures to restore the satisfaction of truth, justice, human dignity, to recognize the violation of law, as well as to take responsibility for correcting the violations.

One of the significant positions of the satisfaction is that satisfaction is non-financial reparation. The recent practice of the international human rights mechanisms argued that the simple recognition of the violation by the State is already sufficient satisfaction. The Inter-American Court, however, considers the simple statement of the fact of human rights violation to be insufficient, as the victim does not receive adequate recognition of the consequences of his or her truth ${ }^{58-59}$.

While public recognition is an important psychological moment for the victim, in addition, it helps to overcome the systematic nature of human rights violations. Such recognition may include, for example, a public statement on behalf of the State, recognizing the fact of human rights violation. Such measures are a common practice for the regional systems, except the African system, where the practice of public declaration of the facts of human rights violations today is not typical for the African Commission and the African Court. Thus, the African Commission does not mention the possibility of the public apology in its recommendations, as stipulated in the UN Basic Principles and Guidelines.

Guarantees of non-repetition: The European Court extended its jurisdiction to decide on the compensation for human rights violations, suggesting some general measures. The Court explained the meaning of Article 46 (1) of the European Convention in the Broniowski case as giving to the Court the authority to develop to confront the human rights violations with systemic nature, which can lead to numerous analogous violations of the European Convention within the same State. Because of their containment function, the common steps can be considered as a guarantee of non-repetition of the disturbance.

The Inter-American Commission sometimes gives specific recommendations for the States to adopt international agreements and, accordingly, to amend national legislation. For example, the Inter-American Commission decided that States should join the InterAmerican Convention on Enforced Disappearances ${ }^{60,61}$; review national legislation on consular protection ${ }^{62}$; bring national legislation into conformity with international obligations in relation to fair trial and the death penalty abolition ${ }^{63,64}$; adopt legislative provisions for protection of the indigenous peoples' property rights as it is in the American Declaration of the Rights and Duties of Man ${ }^{65}$.

For example, in the Last Temptation of Christ case the Inter-American Court obliged Chile to change its legislation on censorship ${ }^{66}$. Another case, that of Trujillo Oroza, ended up by the Court ordering the State to introduce into national criminal law the legal sanctions for the enforced disappearance ${ }^{67}$. Having considered the Barrios Altos case, the Court decided that the legislative provisions on amnesty in Peru do not create conditions for adequate prosecution of the gross human rights violations ${ }^{68}$.

Noting similar tendencies between the African and the Inter-American systems, we should conclude that the first one, at this moment, is definitely inferior.

\section{Conclusion}

Taking into account that the European human rights protection system developed, inter alia, the most experienced practice on the right to reparation, the two remaining ones- The African and Inter-American human rights protection systems are actively developing mechanisms which have even unique approaches in cases of reparation for victims suffered due to the human rights violations. In addition, we can state that all the current regional systems have their both weak and progressive features. It is useful to study the experience of them all and to accumulate mutual practices and the use of certain measures, of course, in terms of local conditions.

Summing up the aforesaid we can conclude that three regional systems for human rights protection share, in general, the same position to the right to reparation, thus, they provide the same definition of direct and indirect victims or the individual and collective victims, and on 
the whole, the notion of who can be granted by reparation and who can seek it in the judicial or administrative procedures.

In the end it is worth noting that the European human rights protection system, as compared with the African and Inter-American ones, has a special tool for supervision over the Court's rulings enforcement in the States-members of the European Convention, which is imposed on the Committee of Ministers of the Council of Europe. On the other side, in the framework of the Inter-American and the African systems not only judicial bodies but quasi-judicial, i.e., the Commissions which notably facilitate the whole procedure, while the Protocol 11 to the 1950 European Convention, which entered into force in November 1, 1998, replaced "European Commission and Court of Human Rights with a new permanent Court".

Nevertheless, all three regional human rights protection systems have the strict tendency to recommend to the States to amend their relevant legislation and there are the States who firstly granted to choose the appropriate type of reparation and only if they fail the Court or Commissions determine what and how to recover harm suffered by the victim.

\section{Acknowledgment}

This paper was financially supported by the Ministry of Education and Science of the Russian Federation on the program to improve the competitiveness of Peoples' Friendship University (RUDN University) among the world's leading research and education centers in the 2016-2020.

\section{Notes}

* Following States voted for the adoption of the document: Argentina, Austria, Belgium, Bolivia, Brazil, Burkina Faso, Chile, Costa Rica, Cyprus, Ecuador, Estonia, Finland, France, Guatemala, Greece, Hungary, Ireland, Italy, Japan, Latvia, Mexico, Nigeria, Norway, Paraguay, Peru, Poland, Portugal, Romania, Slovenia, Spain, Sweden, Switzerland, the Czech Republic, the Dominican Republic, the Netherlands, the United Kingdom, Uruguay and Venezuela. Abstained from voting: Australia, Egypt, Eritrea, Ethiopia, Germany, India, Mauritania, Nepal, Qatar, Saudi Arabia, Sudan, the United States and Togo.

\section{References}

1. The UN Basic Principles and Guidelines on the Right to a Remedy and Reparation for Victims of Gross Violations of International Human Rights Law and Serious Violations of International Humanitarian Law, U.N. Doc. E/CN. 4/2005/L. 48 (13 April 2005, adopted by General Assembly resolution 60/147 of 16 December 2005). Available from: http://www.ohchr.org/EN/Professionalinterest/Pages/ RemedyAndReparation.aspx

2. Abashidze AKh. Human Rights and Globalization. Russian Annual Collection of International Law. St. Petersburg: SKF "Rossiia-Neva"; 2002. p. 301-7.

3. Abashidze AKh, Alisievich ES. Law of the Council of Europe. Convention for the protection of human rights and fundamental freedoms. Moscow: Mezhdunarodnye Otnosheniia Publishing House; 2007.

4. Hunt M. State obligations following from a judgment of the european court of human rights. In: Christou TA, Raymond JP, editors. European Court Of Human Rights: Remedies and Execution of Judgments. London: British Institute of International and Comparative Law; 2005. p. 26-47.

5. De Greiff P. The Handbook of Reparations. Oxford University Press; 2006.

6. De Greiff P, Duthie R, editors. Transitional Justice and Development: Making Connections. New York: Social Sciences Research Council; 2009.

7. van Boven T. Victims' rights to a remedy and reparation: The new United Nations principles and guidelines. In: Ferstman, et al., editor. Reparations for Victims of Genocide, War Crimes and Crimes against Humanity. Koninklijke Brill NV; 2009. p. 19-40.

8. Bassiouni MCh. Final report: Civil and political rights, including the questions of: Independence of the judiciary, administration of justice, impunity. UN Doc. E/CN.4/2000/62; 2000. Available from: http://userpage.fu-berlin.de/theissen/pdf/Basic\%20Principles\%20Right\%20to\%20Reparation\%20(Bassiouni\%202000).pdf

9. Sandoval-Villalba C. Rehabilitation as a form of reparation under international law. The Redress Trust; 2009. Available from: http://www.redress.org/downloads/publications/ The\%20right\%20to\%20rehabilitation.pdf

10. Sandoval-Villalba $\mathrm{C}$. The concepts of injured party and victim of gross human rights violations. The Jurisprudence of the Inter-American Court of Human Rights: A Commentary on their Implications for Reparations. In: Reparations for Victims of Genocide, War Crimes and Crimes against Humanity. Collection. 2009. p. 243-82. DOI: 10.1163/ ej.9789004174498.i-576.75.

11. Shelton DL. Remedies in international human rights law. 3rd ed. Oxford University Press; 2015.

12. McCrackenK. Commentary on the basic principles and guidelines on the right to a remedy and reparation for victims of gross violations of international human rights law and serious violations of international humanitarian law. Revue internationale de droit penal. 2005; 76:77-9. 
13. European convention for the protection of human rights and fundamental freedoms. 1950. Available from: http:// www.hri.org/docs/ECHR50.html

14. ECtHR, Case Aksoy v Turkey, Judgment of 18 December 1996, Reports 1996-VI, para 113. Available from: http:// www.univie.ac.at/bimtor/dateien/ecthr_1996_aksoy_vs_ turkey.txt

15. ECtHR, Case Çakici v Turkey, Judgment of 8 July 1999, Reports 1999-IV, para 130.

16. ECtHR Case Aktas v Turkey, Judgment of 24 April 2004, para 364.

17. African Commission, case Malawi African Association et al. v Mauritania, Communications 54/91, 61/91, 98/93, 164/97, 196/97, 210/98 (27th Ordinary Session, May 2000). Available from: http://www1.umn.edu/humanrts/africa/ comcases/54-91.html

18. IACtHR in Street Children v Guatemala, Judgment on the merits, 19 November 1999, paras. 99-101. Available from: http://www.corteidh.or.cr/index.php/en/jurisprudencia

19. IACtHR (Judgment) in MassacresdeItuangovColombia, para. 264. Available from: http://www.corteidh.or.cr/index. php/en/jurisprudencia

20. African Commission. Available from: http://www.achpr.org/files/sessions/46th/comunications/276.03/achpr46_276_03eng.pdf

21. African commission, principles and guidelines on the right to a fair trial and legal assistance in Africa. Available from: http://www.achpr.org/instruments/fair-trial/

22. African charter on human and peoples' rights; 1981. Available from: http://www.achpr.org/instruments/achpr/

23. Abashidze AKh, Solntsev AM. Anniversary of the African Charter of human and peoples' rights. Eurasian Law Journal. 2012; 2:22-5.

24. IACtHR. Ticona Estrada and others $\mathrm{v}$ Bolivia.Judgment (Merits, Reparations and Costs), 2008 Nov 27; para. 110. Available from: http://www.corteidh.or.cr/docs/casos/articulos/seriec_199_ing.pdf

25. IACtHR. Gonzaléz, et al. (“Cotton Field”) v Mexico. Judgment (Preliminary Objection, Merits, Reparations, and Costs) of 16 November 2009, paras. 450-451. Available from: http://www.corteidh.or.cr/docs/casos/articulos/seriec_205_ing.pdf_

26. IACtHR. Rochela v Colombia. Judgment (Merits, Reparations and Costs), 11 May 2007, para. 286. Available from: http://www.corteidh.or.cr/docs/casos/articulos/seriec_163_ing.pdf

27. ECtHR.Z. a.o. v. The United Kingdom, 10 May 2001 (Appl. no. $29392 / 95)$ para. 103. Available from: http://www.refworld.org/docid/45ccab042.html

28. Harris DJ, O'Boyle M, Warbrick C. Law of the European Convention on Human Rights. London; 1995.

29. ECtHR. De Wilde, Ooms \& Versyp v. Belgium" (just satisfaction), 10 March 1972 (Appl. nos. 2832/66 a.o.) paras. 15-16. Available from: http://www.globaldetentionproject. org/fileadmin/docs/De-Wilde-Ooms-and-Versyp-v-Belgium-1971.pdf

30. American Convention on Human Rights; 1969. Available from: https://www.oas.org/dil/treaties_B-32_American_ Convention_on_Human_Rights.htm

31. African Commission, Rules of Procedure, Rule 118 (1). Available from: http://www.achpr.org/instruments/ rules-of-procedure-2010/

32. Inter-American Commission, Rules of Procedure, Rule 3. Available from: http://www.oas.org/en/iachr/mandate/Basics/ rulesiachr.asp

33. Draft Articles on Responsibility of States for Internationally Wrongful Acts, in Report of the International Law Commission on the Work of its Fifty-third Session, UN GAOR 56th Sess, Supp No 10, at 43, U.N. Doc. A/56/10; 2001. Available from: http://legal.un.org/ilc/texts/instruments/ english/commentaries/9_6_2001.pdf

34. Case Concerning the Factory at Chorzyw (Claim for Indemnity) (The Merits), P.C.I.J., Series A No 17; 1928 Sep 13. p. 47.

35. ECtHR. Papamichalopoulos and Others v. Greece”, application no. 14556/89, Judgment, 1995 Oct 31, para. 34. Series A No. 330-B.

36. ECtHR. Elci and others v Turkey", applications nos. 23145/93 and 25091/94, Judgment 13 November 2003, paras.721-722. Available from: http://echr.ketse.com/ doc/23145.93-25091.94-en-19961202/

37. Shelton D. Remedies in International Human Rights Law. 3rd ed. Oxford; 2015.

38. ECtHR. Selecuk and Asker v. Turkey. App Nos. 23184/94 and 23185/94, 26. Eur H R Rep. 1998; 477:125.

39. Barkhuysen T, van EmmerikL M. A comparative view on the execution of judgments of the european court of human rights. In: Christou TA, Raymond JP, editors. European Court Of Human Rights: Remedies and Execution of Judgments. London: British Institute of International and Comparative Law; 2005. p. 1-23.

40. African Commission, Sudan Human Rights Organisation \& Centre on Housing Rights and Evictions (COHRE) v Sudan, disposit if (para.229 (d)). Available from: http://www. worldcourts.com/achpr/eng/decisions/2009.05_SHRO_v_ Sudan.htm

41. African Commission. John K. Modise v Botswana. Communication 7/93_14AR. Available from: http://www.worldcourts.com/achpr/eng/decisions/Undated_Modise_v_Botswana_AR10.htm

42. African Commission. John D. Ouko v Kenya. Communication 232/99. Available from: http://www.worldcourts.com/ achpr/eng/decisions/2000.11_Ouko_v_Kenya.htm

43. African Commission. Centre for minority rights development (Kenya) and minority rights group (on behalf of Endorois Welfare Council) v Kenya. Communication 276/03, dispositif, point (a). Available from: https://www.hrw.org/ sites/ default/files/related_material/2010_africa_commission_ruling_0.pdf

44. IACtHR. Loayza Tamayo v Peru, Judgment (Reparations). 27 November 1998, para. 122. Available from: http://www. univie.ac.at/bimtor/dateien/iacthr_1997_loayza-tamayo_ vs_peru.pdf

45. Keburiya ChO. Reparation in the context of remedies for 
the violation of human rights: Law and theory. Eurasian Law Journal. 2016; 6(85):298.

46. ECtHR. Case Scozzari and Giunta v. Italy, App. Nos. 39221/98 and 41963/98, 35. Eur H R Rep. 2000; 12:250.

47. ECtHR. Case Goodwin v. United Kingdom, App. No. 17488/90, 22. Eur H R Rep. 1996; 123:48-50.

48. ECtHR. Case Miloslavsky v. United Kingdom, App. No. 18139/91, 20. Eur H R Rep. 1995; 442:73-4.

49. Mowbray A. Cases, materials, and commentary on the European convention on human rights. 3rd ed. Oxford University Press; 2012. P. 867-88.

50. Wright J. Tort law and human rights. Oxford: Hart Publishing; 2001. p. 40.

51. ECtHR. Case Ipek and others v Turkey, Judgment of 17 February 2004, par a 237; Case Aktas v Turkey, Judgment of 24 April 2003, para 361.

52. ECtHR. Case Orhan v Turkey, Judgment of 18 June 2002, para 443.

53. IACtHR. Cantoral Benavides v Peru. Judgment, 3 December 2001, para.53. Available from: http://www1.umn.edu/ humanrts/iachr/C/88-ing.html

54. IACtHR. Suárez-Rosero v. Ecuador. Judgment (Reparations and Costs), 20 January 1999, para. 60.

55. African Commission. Egyptian Initiative for Personal Rights and Interights v. Egypt. Communication 334/06. Available from: http://www.worldcourts.com/achpr/eng/ decisions/2013.10.12_EIPR_v_Egypt.pdf

56. African Commission. Purohit and Moore v The Gambia. Communication 241/2001, dispositif. Available from: http://www.univie.ac.at/bimtor/dateien/acomhpr_2003_ purohit_andanother_v_gambia.pdf
57. Case Aloeboetoe et al v Suriname (Reparations), Judgment of 10 September, 1993, Series C No 15, para 96. Available from: http://www1.umn.edu/humanrts/iachr/C/11-ing. html

58. Case El Amparo v Venezuela (Reparations), Judgment of 14 September 1996, Series C No 28, para 35. Available from: http://www1.umn.edu/humanrts/iachr/ampa9-14.htm

59. Case of Panel Blanca v Guatemala (Reparations). Judgment of 25 May 2001, Series C No 76, para 105. Available from: http://wwwl.umn.edu/humanrts/iachr/C/76-ing.html

60. Report No 51/99, Case 10.471. Anetro Castillo Pero et al (Peru), 13 April 1999, para 151(4).

61. Report No. 101/01, Case 10.247 et al, Extrajudicial Executions and Forced Disappearances of Persons (Peru), 11 October 2001, para 253 (4).

62. Report No. 52/02, Merits, Case 11.753, Ramón MartínezVillareal (United States), 10 October 2002, para 101 (2).

63. Report No. 55/02, Merits, Case 11.765, Paul Lallion (Grenada), 21 October 2002, para 119 (2-4).

64. Report No. 58/02, Merits, Case 12.275, Denton Aitken, 21 October 2002, para 161(2-5).

65. Report No. 75/02, Case 11.140, "Mary and Carrie Dann" (United States), 27 December 2002, para 173.

66. Case of The Last Temptation of Christ v Chile. Judgment of 5 February 2001, Series C No 73. para 88.

67. Case Trujillo Oroza v Bolivia (Reparations), Judgment of 27 February 2002, Series C No 92. para 122.

68. Case of Barrios Altos v Peru. Interpretation of the Judgment on the Merits, Judgment of 3 September 2001, Series C No 83, para 18 and operative para 2. 